\title{
Functional Tests Elapsed Time
}

National Cancer Institute

\section{Source}

National Cancer Institute. Functional Tests Elapsed Time. NCI Thesaurus. Code C162136.

The interval between two functional test reference time points. 